\title{
EKSISTENSI PENGERAJIN HIASAN JANUR DENGAN STRATEGI COST REDUCTION
}

\author{
Putu Dian Pradnyanitasaria*, Ni Made Intan Priliandani ${ }^{b}$, Ni Made \\ Rai Juniarianic, I Nyoman Endrad \\ a,b,c,dUniversitas Warmadewa, Jalan Terompong No. 24, Denpasar, Bali, \\ Indonesia \\ *(dianpradnya@gmail.com)
}

\begin{abstract}
ABSTRAK
Penjor merupakan simbol dari perayaan keagamaan pada masyarakat Hindu di Bali yaitu perayaan Hari Raya Galungan, dimana penjor akan ditancapkan di lebuh (didepan pintu rumah) umat Hindu di Bali. Penelitian ini diharapkan dapat membantu pengerajin hiasan janur di Bali khususnya di Kabupaten Badung dalam memperhitungkan biaya yang dianggap dapat menimbulkan pemborosan melalui strategi cost reduction. Penelitian ini merupakan penelitian deskriptif kualitatif dengan proses pengumpulan data melalui observasi, wawancara dan dokumentasi. Analisis data menggunakan analisis data model interaktif dengan tiga alur analisis, yaitu kondensasi data (data condensation), penyajian data (display data), serta pengambilan kesimpulan atau verifikasi (conclusion drawing/verification). Hasil dari penelitian ini adalah (1) harga jual hiasan janur oleh para pengerajin bisa berbeda-beda tergantung dari hasil atau model masing-masing hiasan janur, dimana harga jual hiasan janur bisa bervariasi dari Rp250.000,- hingga Rp350.000,-, (2) pengerajin hiasan janur dapat melakukan strategi cost reduction dengan cara meminimalisasi harga biaya bahan baku, yang dalam hal ini dengan membuat sendiri hiasan bunga ratna dari benang wol, (3) untuk mempertahankan eksistensinya para pengerajin hiasan janur diharapkan mampu melakukan inovasi baik dari sisi hasil kerajinan maupun mampu mengembangkan bidang usahanya.
\end{abstract}

Kata kunci: Cost Reduction, Eksistensi, Pengerajin, Hiasan Penjor

\begin{abstract}
Penjor is a symbol of religious celebration in the Hindu community in Bali, which is the celebration of Hari Raya Galungan, where the penjor will be planted in front of the house of Hindus in Bali. This research is expected to be able to help craftsmen in Bali decoration, especially in Badung Regency in calculating costs which are considered to cause waste through a cost reduction strategy. This research is a qualitative descriptive study with the process of collecting data through observation, interviews with craftsmen, and documentation. Data analysis is done using interactive model data analysis with three flow analysis, namely data condensation (data condensation), data presentation (data display), and conclusions or verification (conclusion drawing/verification). The results of this study are (1) the selling price of decorative janur by craftsmen can vary depending on the results or models of each decorative janur, where the selling price of decorative janur can vary from IDR 250,000 to IDR 350,000. (2) craftsmen can
\end{abstract}


make a cost reduction strategy by minimizing the cost of raw materials, in this case by making a ratna flower decoration from wool yarn, (3) to maintain the existence of the decorative craftsmen who are expected to be able to innovate both from the side handicrafts and able to develop their business fields.

Keywords: Cost Reduction, Existence, Craftsman, Penjor Ornament

\section{PENDAHULUAN}

Bali merupakan salah satu pulau di Indonesia yang telah diakui keindahannya oleh dunia. Keindahan pulaunya juga menjadikan Bali sebagai objek pariwisata primadona di Indonesia. Luas wilayah Bali adalah $5.636,66 \mathrm{~km} 2$ dengan total penduduk 4.230.051 juta jiwa (Bappeda Prov Bali, 2018). Penduduk mayoritas di Bali menganut agama Hindu, dimana kepercayaan agama Hindu di Bali sangat kental dengan budaya, tradisi dan adat istiadatnya. Kebudayaan, tradisi dan adat istiadat ini dapat dilihat dengan banyaknya hari Raya Keagamaan yang dimiliki umat Hindu di Bali. Adapun hari raya yang dianut umat Hindu di Bali adalah Hari Raya Nyepi, Hari Raya Galungan, Hari Raya Kuningan, Hari Raya Pagerwesi, Hari Raya Saraswati dan Hari Raya Siwalatri.

Kepercayaan masyarakat Hindu Bali dalam merayakan setiap hari raya dilakukan dengan membuat persembahan sesuai dengan makna dari hari raya tersebut. Salah satunya Hari Raya Galungan dimana makna dari hari raya ini adalah kemenangan "Dharma melawan Adharma", dimana simbol dari makna Hari Raya Galungan ini adalah dengan menancapkan penjor di lebuh (didepan pintu masuk rumah) sebagai wujud serta umat Hindu dalam menegakkan kebenaran sejati, dimana kebenaran yang unggul (Subagiasta, 2010).

Ada 2 jenis penjor yang sering digunakan masyarakat di Bali, yaitu penjor sakral dan penjor profan (Atmaja dkk, 2008). Penjor profan atau yang dikenal dengan pepenjoran merupakan jenis penjor yang digunakan sebagai penghias di hotel, Pesta Kesenian Bali, dan beberapa event diluar upacara keagamaan.

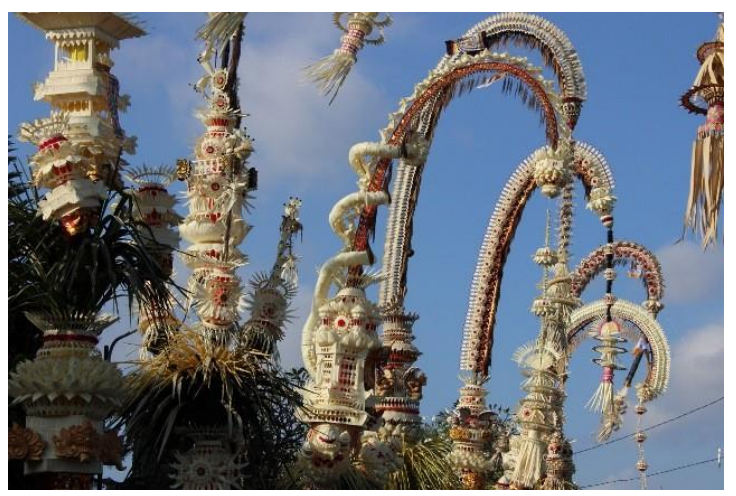

Gambar 1. Penjor Profan Sumber: Bali Express, 2018

Sedangkan penjor sakral adalah penjor yang digunakan pada upacara agama umat Hindu, salah satunya penjor Galungan. Bahan-bahan untuk 
membuat penjor secara filosofi berasal dari hasil pertanian, seperti plawa (daun-daunan), palawija (biji-bijian seperti padai atau jagung), pala bungkah (umbi-umbian), pala gantung (kelapa dan pisang), satu batang bambu dan hiasan dari busung (daun kelapa muda).

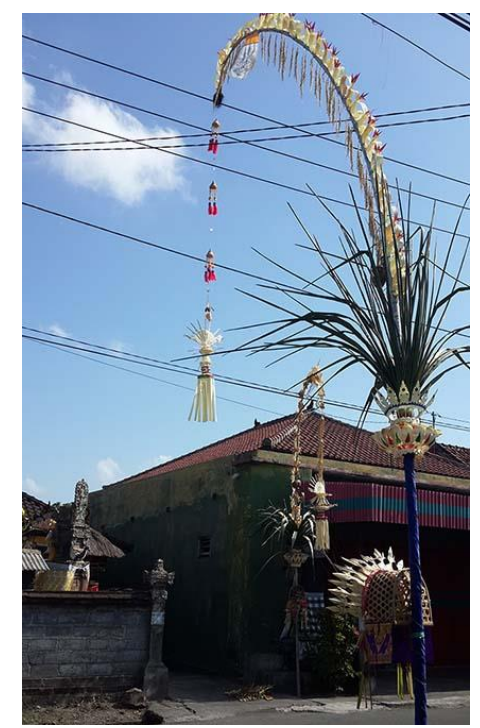

Gambar 2. Penjor Sakral. Sumber: Input Bali, 2015

Bahan-bahan pembuat penjor ini merupakan bahan lokal yang dapat diperoleh masyarakat dengan mudah, namun seringkali bahan utama penjor seperti busung Bali pada saat mendekati hari raya keagamaan sulit dicari sehingga seringkali penjual busung mendatangkan busung dari daerah luar Bali seperti dari Sulawesi. Selain kelangkaan busung pada saat hari raya keagamaan, penggunaan busung baik busung Bali maupun busung Sulawesi pada penjor sangat tidak awet atau cepat layu, apalagi peruntukan penjor yang ditancapkan di lebuh rumah umat Hindu yang merayakan Galungan selama 1 bulan penuh menyebabkan penjor terpapar sinar matahari sehingga hiasan busung pada penjor menjadi layu. Faktor-faktor ini yang menjadikan beberapa alasan dari peralihan penggunaan busung menjadi ental.

Peralihan hiasan janur pada penjor dari busung menjadi daun ental dikarenakan daun ental memiliki daya tahan yang lebih lama daripada hiasan dari busung, selain itu hiasan dari ental ini juga dapat dibentuk menjadi beraneka ragam serta memiliki seni yang menarik karena dapat ditambahkan variasi yang berisi dengan bunga-bunga dan bentuk-bentuk naga ataupun burung, yang menyebabkan bentuknya menjadi semarak. Modal dalam pembuatan hiasan janur untuk masing-masing bahan yaitu harga untuk seikat busung berkisar $\mathrm{Rp}$ 6.000,- sampai dengan Rp 7.000,sedangkan untuk ental harganya memang cukup mahal yaitu berkisar Rp 14.000,- dikarenakan daun ental yang didatangkan dari luar Bali.

Pada penelitian ini, peneliti tertarik dengan cara pembuatan hiasan janur dari ental yang dilakukan oleh pengerajin Ibu $\mathrm{Ni}$ Ketut Ayu Wartini dan Bapak I Putu Surya Juliantara, dimana Ibu Ni 
Ketut Ayu Wartini merupakan ibu rumah tangga yang melakukan industri kreatif rumah tangga dengan membuat hiasan janur dari ental dan dititipkan pada warung penjual hiasan janur di wilayah Kapal. Biasanya ibu Ketut selalu memulai proses produksi hiasan janur tiga bulan sebelum hari Raya Galungan, dimana Ibu Ketut telah memiliki warung langganan sehingga dari pihak warung langganan tersebut telah memesan secara khusus hiasan janur yang dibuat oleh ibu Ketut, harga kisaran ibu Ketut menjual hasil hiasan janurnya kepada pemilik warung langganannya adalah sekitar Rp 350.000,- dengan modal untuk pembelian bahan sekitar Rp 135.000,-, seperti ental, gabus, bunga ratna dari wol, bunga jepun kertas, steples, pita jepang, pita tepi, lem dan biaya kirim.

Pengerajin hiasan janur lainnya yaitu Bapak I Putu Surya Juliantara juga merupakan pengerajin rumahan, bedanya selain menitipkan produknya di warung penjual hiasan janur di Kapal Bapak Putu juga memiliki toko sendiri tempat beliau membuat dan menjajakan produk hiasan janur hasil karyanya. Untuk hiasan janur yang dititipkan di warung di daerah Kapal Bapak Putu mematok harga Rp 250.000,- tapi untuk hasil janur yang dijual ditokonya sendiri Pak Putu mematok harga Rp 270.000,-. Untuk modal pembuatan hiasan janur Pak Putu mengeluarkan modal Rp 105.000,- untuk pembelian ental, gabus, bunga ratna dari wol, bunga jepun kertas, steples, pita tepi dan biaya kirim.

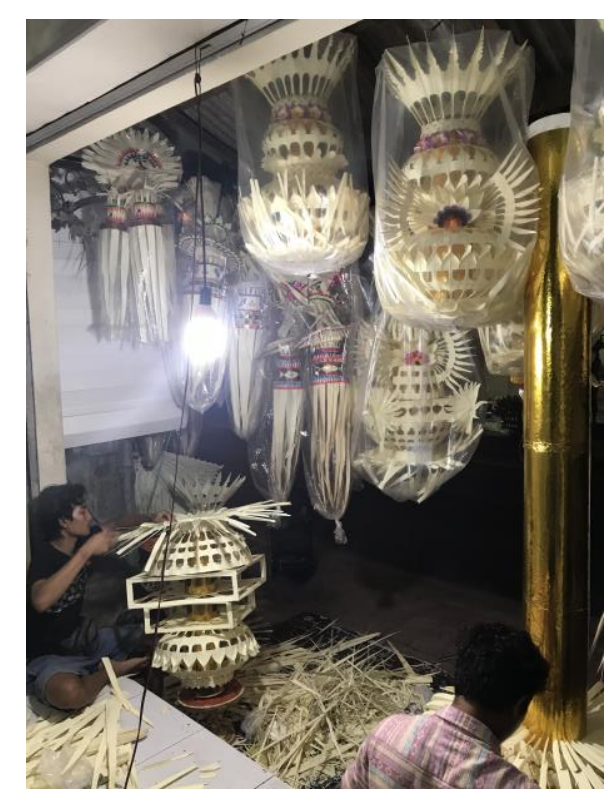

Gambar 3. Proses Pembuatan Janur

Dari kedua pengerajin tersebut terdapat perbedaan dari penggunaan modal maupun penjualan hasil produksi pada masing-masing pengerajin, dimana semakin berkembangnya model dan jenis hiasan janur ini membuat pengerajin hiasan janur harus menambah kreatifitasnya dalam membuat hiasan janur yang indah dan memiliki nilai seni yang baik namun juga tetap memperoleh keuntungan unruk mempertahankan eksistensi mereka. Eksistensi ini dapat diartikan selain dengan keterampilan pengerajin 
hiasan janur dalam membuat hiasan janur yang indah, dapat diimbangi dengan penggunaan ataupun pengolahan bahan tambahan pada perencanaan produksi. Seperti yang dijelaskan oleh Hansen and Mowen (2006) dimana strategi cost reduction sebagai pengelolaan siklus biaya (lifecycle cost management) yaitu bertumpu pada tahap awal siklus produksi. Pengerajin harus mampu melihat biaya bahan baku mana yang dapat diefisienkan sehingga hasil produksi memiliki nilai tambah dan menghasilkan keuntungan bagi pengerajin, sehingga mampu dalam bersaing dengan hasil pengerajin lainnya.

Penelitian yang dilakukan oleh Priwibowo, dkk (2015) menemukan bahwa dengan menggunakan metode Target Profit Pricing dan Cost Reduction yang dilakukan pada CV. Karunia Maha Cipta dalam memproduksi Tepung Mocaf, perusahaan dapat memperoleh keuntungan dengan cara penurunan biaya produksi sehingga perusahaan dapat bersaing dengan perusahaan lainnya.

Mengacu pada penelitian yang tersebut, peneliti juga ingin melakukan penelitian yang berkaitan dengan cost reduction, khususnya berkaitan dengan pengefisienan bahan baku. Perbedaan pada penelitian sebelumnya adalah terletak pada obyek penelitian, yaitu pada pembuatan hiasan janur Penjor Galungan. Hal ini dilakukan karena masih sedikit penelitian yang menggunakan metode cost reduction dalam menentukan harga pokok produksi. Berdasarkan latar belakang di atas, maka pertanyaan yang diajukan dalam penelitian ini adalah "Bagaimana cara pengerajin dalam mempertahankan eksistensinya dan bahan apa saja yang dapat diefisienkan sesuai dengan metode cost reduction".

\section{TELAAH LITERATUR}

\section{Akuntansi Biaya}

Menurut Kholmi dan Yuninsih (2009) Akuntansi biaya merupakan proses pelacakan, pencatatan, pengalokasian, serta pelaporan yang disertai analisis terhadap berbagai macam biaya-biaya yang berkaitan dengan aktivitas produksi sebuah perusahaan dalam menghasilkan barang atau jasa.

Mulyadi (2010) menyatakan bahwa biaya adalah pengorbanan sumber ekonomis yang diukur dalam satuan uang, yang telah terjadi, sedang terjadi atau yang kemungkinan akan terjadi untuk tujuan tertentu. Dari definis, dapat disimpulkan bahwa biaya dapat didefinisikan atau diartikan dalam 
dua kategori, yaitu secara sempit dan luas. Dalam arti sempit, definisi atau pengertian biaya merupakan pengorbanan sumber ekonomi untuk memperoleh aktiva, sedangkan dalam arti luas, definisi atau pengertian biaya merupakan pengorbanan sumber ekonomi yang dapat diukur dalam satuan uang yang telah terjadi atau secara potensial akan terjadi untuk mencapai tujuan tertentu.

Biaya adalah pembayaran kas atau ekuivalennya atau komitmen untuk membayar kas di masa depan dengan tujuan memperoleh pendapatan (Niswonger, 2000). Dalam perusahaan manufaktur dapat dibedakan menjadi tiga yaitu:

1. Bahan, biaya bahan yang merupakan bagian integral dari produk diklasifikasikan sebagai biaya bahan langsung (direct materials cost). Dalam praktek, biaya bahan langsung tidak hanya merupakan bagian integral dari barang jadi, tetapi juga merupakan bagian yang signifikan dari total biaya produk. Biaya bahan yang bukan merupakan bagian yang siginifikan dari total biaya produk disebut bahan tidak langsung (indirect materials). Bahan tidak langsung dikelompokkan sebagai bahan dari overhead pabrik.
2. Tenaga kerja pabrik, biaya upah dan gaji karyawan yang secara langsung telibat dalam mengubah bahan menjadi produk jadi diklasifikasikan sebagai biaya tenaga kerja langsung (direct-labor cost). Biaya tenaga kerja yang tidak secara langsung berhubungan dengan pembuatan produk disebut tenaga kerja tidak langsung (indirect labor).

3. Biaya overhead pabrik, biayabiaya selain dari biaya bahan baku langsung dan biaya tenaga kerja langsung yang dikeluarkan dalam proses produksi diklasifikan sebagai biaya overhead pabrik (factory-overhead cost), yang kadang-kadang disebut juga biaya overhead manufaktur (manufacturing overhead).

\section{Pengertian Strategic Cost Reduction \\ Lingkungan bisnis yang} kompetitif menuntut personel perusahaan untuk mampu mengurangi biaya dalam jumlah yang signifikan dan untuk jangka waktu panjang. Pengurangan biaya seperti ini disebut sebagai pengurangan biaya yang bersifat strategis (strategic cost reduction). Berikut ini disajikan fakta yang berkaitan dengan strategic cost reduction (Mulyadi, 2003). 
1. Strategic cost reduction mencakup jangka waktu panjang. Dengan ini strategic cost reduction memerlukan sistem informasi biaya yang mencakup jangka panjang, yang dapat menghasilkan informasi product life cycle costs.

2. Strategic cost reduction akan efektif jika difokuskan pada tahap perencanaan, bukan pada tahap implementasi rencana.

3. Strategic cost reduction menjadikan pengurangan biaya bagian strategi untuk menempatkan perusahaan pada posisi kompetitif, sehingga mencakup keseluruhan rantai nilai (value chain), bukan hanya pengurangan biaya pada tahap produksi, apalagi hanya berkaitan dengan pengurangan biaya tenaga kerja.

4. Pencatatan biaya yang telah terjadi tidak dapat mempengaruhi perilaku manajemen di dalam mengkonsumsi sumber daya, sedangkan strategic cost reduction membutuhkan sistem informasi biaya yang dapat mempengaruhi perilaku manajemen dalam melakukan improvement secara berkelanjutan.

Pengurangan biaya dalam strategic cost reduction terjadi setelah hasil peningkatan bertahap terhadap kualitas, keandalan (dependability), dan kecepatan (speed) (Mulyadi, 1998). Improvement terhadap kualitas, keandalan, dan kecepatan perusahaan sebagai penghasil produk inilah yang sesungguhnya mengakibatkan pengurangan total biaya yang dibebankan kepada konsumen.

Improvement terhadap tiga hal tersebut tidak dapat dilaksanakan melalui pendekatan jangka pendek, partial (hanya difokuskan pada biaya tertentu), dan periodik, namun harus dilaksanakan melalui pendekatan jangka panjang, bersistem (system approach), dan berkelanjutan. Implikasi dari pengurangan biaya jangka panjang yang sukses didapat secara tidak langsung melalui keberhasilan dari strategi-strategi lain. Oleh karena itu strategic cost reduction harus selalu menyertai strategi bersaing perusahaan.

\section{METODE}

\section{Pendekatan Penelitian}

Penelitian ini menggunakan pendekatan deskriptif kualitatif karena penelitian ini bertujuan untuk memperoleh gambaran secara utuh dan menyeluruh mengenai pemahaman metode cost reduction dari para pengerajin hiasan janur, yang diuraikan dalam bentuk kata- 
kata (deskripsi). Selain itu, penelitian ini juga mengamati pengerajin hiasan janur sesuai dengan fakta di lapangan yang dilakukan melalui interaksi langsung dengan mereka ataupun pengamatan (observasi) di lapangan.

\section{Lokasi Penelitian}

Penelitian ini merupakan penelitian di lapangan, dimana merupakan pengerajin yang menitipkan produknya pada warung yang menjual hiasan janur di wilayah desa Kapal, kecamatan Mengwi, Kabupaten Badung. Peneliti memilih wilayah desa Kapal sebagai lokasi penelitian karena didaerah tersebut merupakan pusat penjualan hiasan janur penjor Galungan. Oleh karena itu, pemilihan lokasi penelitian dirasa tepat oleh peneliti karena fokus penelitian untuk memperoleh penjelasan secara menyeluruh mengenai cara pembuatan hiasan janur penjor Galungan dan sejauh mana pengerajin hiasan janur dapat memahami proses produksi sehingga dapat menentukan efisiensi biaya yang dapat dilakukan.

\section{Sumber Data}

Sumber data utama penelitian diperoleh melalui observasi dan wawancara terhadap informan yang merupakan pengerajin hiasan janur penjor Galungan. Interaksi awal (survey awal) dengan pada pengerajin, saat ini harga bahan baku hiasan janur yaitu ental mengalami kenaikan, sehingga pengerajin masih sulit menentukan harga jual produk. Adapun data dari pengerajin yang diajak dalam interaksi awal adalah ibu Ni Ketut Ayu Wartini yang berasal dari daerah Kapal, dimana pengerajin tersebut telah 7 tahun menekuni pembuatan hiasan janur penjor galungan dan Bapak I Putu Surya Juliantara yang telah menekuni pembuatan hiasan janur sejak 5 tahun terakhir. Sumber data tambahan penelitian ini diperoleh dari hasil dokumentasi dan catatan observasi yang dibuat selama proses penelitian.

\section{Teknik Pengumpulan Data}

Penelitian ini berdasarkan fakta yang ada di lapangan dengan menggunakan observasi partisipan, wawancara tidak terstruktur, dan dokumentasi. Observasi partisipan dilakukan melalui pengamatan langsung terhadap proses pembuatan hiasan janur penjor Galungan. Wawancara tidak terstruktur (unstructured interview), dimana wawancara dilakukan tidak menggunakan pedoman wawancara yang sistematis, hanya menggunakan garis-garis besar permasalahan yang akan ditanyakan, bahkan lebih 
seperti berkomunikasi secara informal. Penggunaan wawancara tidak berstruktur diharapkan dapat memberikan kebebasan dan kenyamanan kepada para informan untuk menjelaskan proses produksi hiasan janur dan menjelaskan bahanbahan apa saja yang diperlukan dalam pembuatan hiasan janur. Dokumentasi merupakan cara untuk mendukung hasil observasi dan wawancara yang telah dilakukan. Dokumentasi dalam penelitian ini menggunakan rekaman wawancara, video, dan gambar (photo) selama observasi di lapangan.

\section{Teknik Analisis Data}

Data yang diperoleh tentu memiliki keunggulan dan kelemahannya sendiri, perlu melakukan analisis terhadap data dikumpulkan untuk memperoleh tangkapan realitas yang lebih valid. Teknik analisis data dalam penelitian ini menggunakan analisis data model interaktif sebagaimana yang dikembangkan oleh Miles, Huberman, dan Saldana (2014), yaitu kondensasi data (data condensation), penyajian data (display data), serta pengambilan kesimpulan atau verifikasi (conclusion drawing/verification). Penelitian ini menggunakan analisis data model interaktif untuk memberikan keyakinan tentang keabsahan data yang diperoleh, sehingga peneliti tidak ragu dalam penarikan kesimpulan terhadap penelitian yang dilakukan.

Proses pertama diawali dengan kondensasi data (data condensation), yaitu proses memilah, menyerdahanakan, dan mentransfromasikan keseluruhan data yang berasal dari hasil observasi dan transkip wawancara yang telah dilakukan selama di lapangan. Proses kedua, penyajian data (display data) merupakan proses pengorganisasian dan penyatuan informasi ke dalam pokok-pokok yang lebih sistematis. Penyajian data dilakukan untuk membantu memahami dan memberikan gambaran keseluruhan informasi secara efektif sebagai dasar pengambilan kesimpulan. Proses terakhir adalah penarikan kesimpulan (conclusion drawing) dari hasil kondensasi data dan penyajian data. Kesimpulan yang dibuat kemudian diverifikasi (verification) dengan cara meninjau ulang catatan lapangan (hasil observasi dengan hasil wawancara) dan mencocokkan dengan teori yang dianggap relevan untuk menghasilan kesimpulan akhir yang lebih jelas dan konkrit.

\section{HASIL DAN PEMBAHASAN Penjualan Hiasan Janur Penjor}

Biaya bahan yang dikeluarkan masing-masing pengerajin, seperti 
pembelian ental, gabus, bunga ratna dari wol, bunga jepun kertas, steples, pita tepi menjadi nilai tambah dalam menghasilkan hiasan janur penjor. Pengerajin hiasan janur seperti Ibu Ketut Ayu dan Bapak Putu Surya melakukan usahanya sendiri dan belum memiliki tenaga kerja tetapi telah memiliki pelanggan sendiri yaitu penjual hiasan janur penjor di daerah Jalan Raya Kapal, dimana pelanggan setiap mendekati Hari Raya Galungan akan langsung memesan model hiasan janur dengan jumlah tertentu, dilain pihak pengerajin seperti Bapak Putu Surya juga menjajakan hasil hiasan janur penjornya pada toko yang lokasinya memang tidak sestrategis penjual hiasan janur di kawasan Jalan Raya Kapal yang notabane merupakan daerah pusat penjualan alat-alat kebutuhan upacara di Bali dan merupakan jalan raya utama Denpasar - Tabanan yang sering dilalui oleh masyarakat Bali.

Hal ini sesuai dengan yang disampaikan oleh Ibu Ketut Ayu, salah satu pengerajin hiasan janur penjor yang hanya menitipkan hasil kerajinanya pada penjual dikawasan Jalan Raya Kapal:

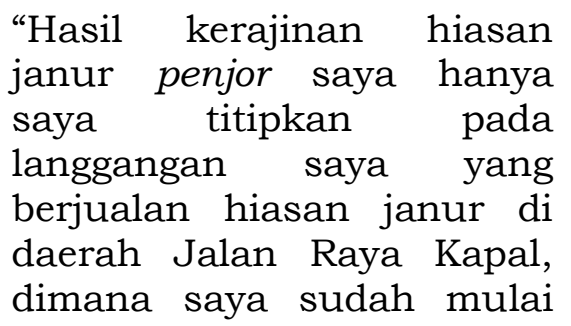

memproduksi hiasan janur 3 bulan sebelum Hari Raya Galungan sesuai model dan pesanan dari langganan saya. Langganan saya di seputaran Jalan Raya Kapal itu ada sejumlah 3 toko, dimana mereka selalu berebut hasil kerajinan saya karena memang hasil kerjainan hiasan janur saya berbeda dari pengerajin yang lain, dimana hiasan janur yang saya buat memiliki bentuk dan hasil yang rapi".

Selain itu penuturan dari pengerajin Bapak Putu Surya tentang hasil hiasan janurnya adalah sebagai berikut:

"Selain saya menjual sendiri
hasil kerajinan hiasan janur
saya di toko saya sendiri
yang berlokasi di desa
Abianbase, saya juga tetap
menitipkan hasil hiasan
janur saya pada toko di
seputaran Jalan Raya
Kapal, karena permintaan
yang besar dari wilayah
sana, selain karena daerah
tersebut memang
merupakan pusat penjualan
kerajianan hiasan janur,
daerah tersebut juga sering
dilalui masyarakat Bali yang
sedang menuju daerah
Denpasar - Tabanan
ataupun sebaliknya".

Dari hasil wawancara yang dilakukan oleh peneliti kepada para pengerajin, diperoleh bahwa terdapat perbedaan dalam proses penjualan hasil kerajinan hiasan janur mereka dimana pengerajin Ibu Ketut Ayu hanya menitipkan barangnya pada 
penjual hiasan janur di Jalan Raya Kapal, sedangkan pengerajin Bapak Putu Surya selain menitipkan hasil kerajinannya di penjual wilayah Jalan Raya Kapal, Bapak Putu juga menjual hasil kerajinan hiasan janurnya di toko milik sendiri.

Selain itu dari sisi harga jual dari hasil wawancara pihak Ibu Ketut Ayu dapat menjual satu hiasan janur seharga Rp350.000,- dengan modal kurang lebih Rp135.000,-, sedangkan dari pihak Bapak Putu Surya untuk hasil hiasan janur yang dititipkan pada penjual di Jalan Raya Kapal harga yang dijajakan senilai Rp250.000,- berbeda dengan harga hiasan janur yang ia jual di tokonya sendiri yaitu senilai Rp270.000,dengan modal kurang lebih Rp105.000,-. Perbedaan dalam penentuan harga jual ini didasari oleh hasil hiasan janur yang mereka buat yaitu dari kerumitan, proses pembuatan dan modal dari hiasan janur yang dihasilan, sedangkan untuk penggunaan bahan yang biasa digunakan oleh masing-masing pihak pengerajin yaitu sebagai berikut:

Tabel 1, Penggunaan Bahan Baku Hiasan Janur

\begin{tabular}{|c|c|c|c|c|}
\hline No & Bahan & Kuantitas & $\begin{array}{c}\text { Harga Bahan Baku } \\
\text { Pengerajin Ibu } \\
\text { Ketut Ayu }\end{array}$ & $\begin{array}{c}\text { Harga Bahan Baku } \\
\text { Pengerajin Bapak } \\
\text { Putu Surya }\end{array}$ \\
\hline 1 & Ental & 2 ikat & Rp 18.000/ikat & Rp 14.000/ikat \\
\hline 2 & Gabus & 1 meter & Rp $15.000,-/$ meter & Rp 15.000,-/meter \\
\hline 3 & $\begin{array}{l}\text { Bunga Jepun } \\
\text { kertas }\end{array}$ & 5 pcs & $\begin{array}{c}\text { Rp } \\
\text { 25.000/bungkus } \\
\text { (isi } 100 \text { pcs) }\end{array}$ & $\begin{array}{c}\text { Rp } \\
27.500 / \text { bungkus } \\
\text { (isi } 100 \text { pcs)b }\end{array}$ \\
\hline 4 & $\begin{array}{l}\text { Bunga Ratna } \\
\text { dari wol }\end{array}$ & 36 pcs & $\begin{array}{l}\text { Rp } 7.500 / \text { bungkus } \\
\text { (isi } 100 \text { pcs) }\end{array}$ & $\begin{array}{l}\text { Rp } 7.500 / \text { bungkus } \\
\text { (isi } 100 \text { pcs) }\end{array}$ \\
\hline 5 & Lem & $\begin{array}{c}\text { Sesuai } \\
\text { kebutuhan }\end{array}$ & $\begin{array}{c}\mathrm{Rp} \\
15.000 / \text { bungkus }\end{array}$ & $\begin{array}{c}\text { Rp } \\
10.000 / \text { bungkus }\end{array}$ \\
\hline 6 & Steples & $\begin{array}{c}\text { Sesuai } \\
\text { kebutuhan }\end{array}$ & $\begin{array}{c}\text { Rp } \\
10.000 / \text { bungkus }\end{array}$ & Rp 8.000/meter \\
\hline 7 & Pita jepang & 1 meter & Rp 5.000/meter & Rp $15.000 /$ meter \\
\hline 8 & Pita Tepi & 1 meter & Rp $10.000 /$ meter & Rp 14.000/ikat \\
\hline 9 & Biaya Kirim & & Rp $15.000 /$ kirim & Rp $50.000,-/$ kirim \\
\hline
\end{tabular}

Penentuan Strategi Cost Reduction

Penjabaran mengenai biaya bahan baku yang digunakan oleh masing-masing pengerajin sesuai yang ditampilkan pada Tabel 1 memperlihatkan terdapat beberapa perbedaan biaya bahan baku yang digunakan oleh para pengerajin, dimana untuk melakukan proses strategi cost reduction peneliti telah melakukan sampel beberapa 
pertanyaan mengenai penggunaan bahan baku pada hiasan janur, dimana diperoleh bahwa biaya bahan baku pembuatan hiasan janur ini sebenarnya bisa diminimalisasi dengan hasil wawancara yang dilakukan kepada pengerajin Ibu Ketut Ayu yaitu:

"Saya sebenarnya berniat untuk membuat bunga ratna sendiri, dimana bahan dasar dari pembuatan bunga ratna ini adalah benang wol yang memiliki banyak warna, sehingga hasil dari hiasan janur saya bisa memiliki nilai tambah".

Pernyataan dari Ibu Ketut Ayu ini sebenarnya merupakan langkah awal dalam melakukan strategi cost reduction terhadap biaya bahan bunga ratna, dimana apabila pembuatan bunga ratna yang berbahan dasar wol ini dilakukan sendiri maka akan terdapat minimalisasi biaya bahan dimana apabila membeli kepada pemasok bunga ratna dipasaran harganya sekitar Rp7.500,- per bungkus denga isi sebanyak 100 pcs bunga ratna sedangkan apabila pengerajin membuat sendiri bunga ratna dari bahan benang wol, pengerajin hanya perlu membeli benang wol segulung seharga Rp5.000,-. Pembuatan bunga ratna ini juga bisa dilakukan pada saat 3 bulan sebelum rencana pembuatan hiasan janur dilakukan, dimana Hari Raya Galungan di Bali dilaksanaan 2 kali dalam setahun dengan jangka waktu setiap 6 bulan sekali, sehingga manajemen waktu pembuatan hiasan janurpun tidak akan terkendala, dimana 3 bulan sebelum pembuatan hiasan janur para pengerajin memiliki waktu luang untuk digunakan dalam pembuatan bunga ratna dari bahan benang wol.

\section{Eksistensi Pengerajin Hiasan Janur}

Dengan adanya banyak pengerajin hiasan janur di Bali dan adanya perbedaan harga jual yang ditawarkan, maka tentu saja eksistensi para pengerajin hiasan janur harus bisa dipertahankan, sehingga para pengerajin hiasan janur juga akan secara langsung harus memiliki cara-cara yang dapat mempertahankan eksistensinya dalam berkarya. Untuk mempertahankan eksistensinya para pengerajin hiasan janur diharapkan terus dapat mengembangkan kemampuannya dalam menciptakan hasil hiasan janur yang lebih menarik dan dapat melakukan minimalisasi biaya bahan baku namun tidak menurunkan kualitas hasil kerajinan hiasan janurnya. Hal ini sesuai dengan pernyataan dari Bapak Putu Surya:

"Saat menjual hiasan janur
ini saya terkadang
terkendala dengan ide


pembuatan hiasan janur, dimana setiap Hari Raya Galungan selalu saja ada model hiasan janur baru yang biasanya timbul, oleh karena itu saya akhirnya mengembangkan usaha saya dengan menyediakan pembuatan penjor dari awal sampai jasa pemasangan ditempat pembeli, karena banyak masyarakat Bali yang memiliki uang lebih, suka melirik jasa pembuatan penjor ini karena menjadi lebih gampang bagi mereka dalam mempersiapkan perayaan Hari Galungan, selain itu juga saya menerima pesanan dari masyarakat yang sedang mempersiapkan pelaksanaan pewiwahan (pesta pernikahan) sehingga saya tetap bisa menjalankan usaha saya ditengah persaingan pasar saat ini”.

Pernyataan dari Bapak Putu Surya ini tentu saja merupakan cara alternatif lainnya selain melakukan strategi cost reduction terhadap biaya bahan baku dalam proses mempertahankan eksistensinya di tengah persaingan pasar saat ini. Lain halnya dengan pengerajin Ibu Ketut Ayu yang memang sudah lama berkecimpung sebagai pengerajin hiasan janur yaitu selama hamper lebih dari 10 tahun, dimana hasil hiasan janur Ibu Ketut memang sudah terkenal dan memiliki hasil hiasan janur yang banyak diminati oleh masyarakat karena model yang bagus dan hasil yang rapi, sehingga setiap perayaan Hari Raya Galungan Ibu Ketut Ayu sudah memiliki pesanan pasti dari para pelanggannya. Hal ini juga dapat menjelaskan bahwa masyarakat sekarang dalam mendirikan penjor di "lebuh" rumahnya ingin menampilkan penjor yang terbaik sesuai dengan status mereka dimasyarakat dimana penjor yang didirikan harus memiliki kualitas terbaik menurut versi pemiliknya sehingga mereka akan berlomba-lomba dalam membeli janur kualitas terbaik sesuai dengan kemampuan mereka.

\section{KESIMPULAN, IMPLIKASI DAN KETERBATASAN PENELITIAN}

Dari hasil penelitian diatas maka dapat disimpulkan bahwa:

1. Harga jual hiasan janur oleh para pengerajin bisa berbeda-beda tergantung dari hasil atau model masing-masing hiasan janur, dimana harga jual hiasan janur bisa bervariasi dari Rp250.000,hingga Rp350.000,-

2. Pengerajin hiasan janur dapat melakukan strategi cost reduction dengan cara meminimalisasi harga biaya bahan baku, yang dalam hal ini dengan membuat sendiri hiasan bunga ratna dari benang wol 
3. Untuk

mempertahankan

eksistensinya para pengerajin

hiasan janur diharapkan mampu melakukan inovasi baik dari sisi hasil kerajinan maupun mampu mengembangkan bidang usahanya.

\section{REFERENSI}

Atmaja, I Made Nada, dkk. 2008. Nilai Filosofis Penjor Galungan dan Kuningan. Surabaya: Paramita.

Bragg, Steven M. 2009. Cost Reduction Analysis: Tools and Strategies. John Wiley \& Son,Inc.

Hansen, D.R. dan M.M. Mowen. 2006. Cost Management: Accounting and Control (5 ed.). Thomson South-Western. Mason.

Kholmi, Masiyah dan Yuningsih. 2009. Akuntansi Biaya Edisi Revisi. UMM Press, Malang.
Mulyadi. 2010. Akuntansi Biaya. Unit penerbit dan percetakan Sekolah Tinggi Ilmu Manajemen YKPN. Yogyakarta.

Niswonger, Rollin C, dkk. 2000. Prinsip-prinsip Akuntansi. Jakarta: Erlangga.

Priwibowo, dkk. 2015. Penetapan Harga Jual Tepung Mocaf Dengan Menggunakan Metode Target Profit Pricing Dan Cost Reduction. Reka Integra ISSN: 2338-5081.

Subagiasta, I Ketut. 2010. Hari Raya Galungan (Kajian Filosofis dan Teologi). Warta Hindu Dharma NO. 527 Nopember 2010.

http://phdi.or.id/artikel/hari-rayagalungan-kajian-filosofis-danteologi-3.

Miles, Mathew B., Michael Huberman, dan Johnny Saldana. 2014. Qualitative Data Analysis-Third Edition. London: Sage Publication Ltd. 